\title{
Pola Komunikasi Interpersonal dalam Membentuk Kemandirian Anak Berkebutuhan Khusus
}

\author{
${ }^{1}$ Rahma Fitri Dayana, ${ }^{2}$ Bunyamin \\ ${ }^{1}$ Institut Pesantren KH. Abdul Chalim, Kabupaten Mojokerto \\ ${ }^{1}$ rahmafd8@gmail.com, ${ }^{2}$ aminbunyaminamin876@gmail.com
}

\begin{abstract}
ABSTRAK
Anak Berkebutuhan Khusus yang di besarkan di lembaga sosial memiliki hak yang sama seperti anak yang tumbuh kembangnya dalam lingkungan keluarga. Salah satu bentuk komunikasi yang terjadi antara pengasuh kepada anak berkebutuhan khsus untuk memberikan motivasi serta nasihat dalam hal membentuk kemandirian adalah komunikasi interpersonal. tujuan penelitian ini adalah untuk membahas bagaiamana tahapan komunikasi interpersonal serta pola komunikasi interpersonal pengasuh Lembaga Kesejahteraan Sosial Anak (LKSA) Villa Do'a Yatim Sejahtera terhadap anak berkebutuhan khusus dalam membentuk kemandirian. Untuk menjawab rumusan masalah diatas penelitian ini menggunakan penelitian berjenis kualitatif yang bersifat deskriptif serta menggunaka teori penetrasi sosial. Adapun hasil penelitian ini adalalah terdapat empat tahapan komunikasi interpersonal yakni tahap orientasi, tahap pertukaran eksplorasi, tahap pertukaran afektif, dan tahap pertukaran stabil yang digunakan oleh pengasuh Lembaga Kesejahteraan Sosial Anak (LKSA) Villa Do'a Yatim Sejahtera kepada anak berkebutuhan khusus serta pola komunikasi roda dan pola komunikasi bintang dapat membentuk kemandirian anak.
\end{abstract}

Kata Kunci: Pola Komunikasi Interpersonal, Anak Berkebutuhan Khusus, Lembaga Kesejahteraan Sosial Anak, Kemandirian.

\section{PENDAHULUAN}

Manusia merupakan makhluk sosial yang hidup berkelompok dan membutuhkan satu sama lain untuk saling berhubungan dan berinteraksi. Dengan adanya hubungan dan interaksi tersebut artinya membutuhkan adanya sebuah komunikasi. komunikasi di anggap sangat penting bagi kehidupan sehari-hari. Komunikasi bisa dilakukan kapan saja dan dimana saja. Melalui komunikasi kita bekerja sama dengan anggota masyarakat (keluarga, kelompok belajar, perguruan tinggi, Rt, Rw, Desa, Kota, dan Negara secara keseluruhan) untuk mencapai tujuan bersama. ${ }^{1}$

\footnotetext{
${ }^{1}$ Dedi Mulyana, Ilmu Komunikasi Suatu Pengantar (Bandung: PT Remaja Rosdakarya, 2016), h.6
} 
Komunikasi merupakan inti dari semua hubungan sosial, yaitu proses dimana penyampaian pesan dari komunikator kepada komunikan. ${ }^{2}$ Menurut pakar komunikasi ada banyak bentuk komunikasi seperti komunikasi interpersonal, komunikasi intrapersonal, komunikasi organisasi, dan lain-lain. Dari banyaknya jenis komunikasi tersebut, komunikasi interpersonal yang paling sering dijumpai. Komunikasi interpersonal tidak hanya menyampaikan sebuah informasi akan tetapi juga bertukar ide, gagasan dan yang berkaitan dengan aktivitas individu maupun kelompok untuk mengubah sikap, perilaku serta pemikiran dengan lebih baik. Komunikasi penting bagi semua orang. Banyak orang mengira bahwa komunikasi merupakan tugas yang mudah. Akan tetapi, orang akan menyadari bahwasannya jika ada hambatan komunikasi (noise), terjadi pada komunikator maka akan mengakibatkan proses komunikasi yang tidak efektif. Situasi ini juga terjadi dalam proses bimbingan dan pendidikan oleh pengasuh bagi anak-anak asuhnya, terlebih bagi pada anak yang berkebutuhan khusus.

Menurut DEPDIKNAS, dibandingkan dengan anak kelompok umur lain, anak berkebutuhan khusus $(\mathrm{ABK})$ adalah anak yang mengalami kelaianan atau kelainan (fisik, intelektual, sosial, emosional) selama tumbuh kembangnya. ${ }^{3}$ Perkembangan kemandiriannya sangat erat kaitannya dengan aturan masa depan, dimana individu harus mampu hidup ditengah-tengah kehidupan bermasyarakat dan bertanggung jawab sesuai dengan standar yang berlaku. Selain itu, kemandirian juga terkait dengan kualitas hidup masa depan mereka dan tentunya akan bersaing dengan orang-orang yang tidak memiliki keterbatasan.

Pengasuh berasal dari kata asuh yang memiliki arti mengurus, mendidik, melatih, mengajar, dan diberi tambahan peng (pengasuh) berarti kata pembimbing, pelatih. ${ }^{4}$ jadi pengasuh mempunyai arti sebagai orang yang mengasuh, mengasuh, melatih, mengurus serta mendidik, tentunya juga dilandasi dengan rasa kasih sayang. Hubungan interpersonal antara anak asuh dan pengasuh yang baik bisa membentuk dan menciptakan keterbukaan dan kedekatan interpersonal.

Bentuk pengasuhan yang dilakukan oleh orang tua harus berkaitan dengan pembentukan kecerdasan, kepribadian dan keterampilan yang sengaja dilakukan, termasuk larangan, perintah, hukuman situasional atau pemberian hadia. ${ }^{5}$ Anakanak asuh menganggap bahwasannya pengasuh merupakan acun atau orang yang akan diikuti serta diteladani. Maka dari itu pola komunikasi yang seperti apa

${ }^{2}$ Ety Nur Inah, Peranan Komunikasi Dalam Pendidikan. Jurnal Al-Ta'dib, Vol 6 No. 1 (2013), hal.178

3 Depdiknas.2004, "Pedoman Peneyelenggaraan Pendidikan Terpadu/Inklusi Jakarta: DitPLB. h.2

${ }^{4}$ Efanke Y. Pioh, Peran Pengasuh Dalam Meningkatkan Kemandirian Anak Disibalitas Netra Di Panti Sosial Bartemeus Manado, E-Jurnal Acta Diurna., Vol. 6 No. 1 (2017)

${ }^{5}$ Syaiful Bahri Djamarah, Pola Asuh Orang Tua dan Komunikasi Dalam Keluarga(Jakarta: PT. Rineka Cipt, 2017), hal.2 
digunakan oleh pengasuh merupakan bentuk dari harapan akan terciptanya pola asuh yang baik pula, begitu juga sebaliknya. Pola komunikasi akan tercipta dengan baik apabila kegiatan pengasuhan anak-anak asuh didasari dengan rasa kasih sayang, cinta serta menjadikan anak asuh sebagai subjek yang harus diajarkan, dibimbing, dan dibina, tidak hanya dijadikan sebagai objek semata.

Cara-cara pengasuhan yang seperti itulah yang seharusnya dilakukan oleh seluruh Lembaga Kesejahteraan Sosial Anak (LKSA) ataupun panti asuhan yang ada. Dalam mendidik serta membina anak-anak asuh Lembaga Kesejahteraan Sosial Anak (LKSA) Villa Do'a Yatim Sejahtera, pengasuh memberikan banyak pemahaman mengenai sikap dan prilaku yang seharusnya ditiru. Lembaga Kesejahteraan Sosial Anak (LKSA) Villa Durian Do'a Yatim Sejahtera menerapkan sistem kekeluargaan dimana semuanya dilakukan secara berjamaah, tidak hanya sholat saja yang dilakukan secara berjamaah akan tetapi kegiatan sehari-hari juga dilakukan berjamaah. Anak-anak yang berusia 13 keatas dalam artian SMP keatas diberi kepercayaan dan dibagi jadwal untuk masak, sedangkan anak-anak SD kebawah tidak diwajibkan untuk ikut masak akan tetapi diperbolehkan bahkan disarankan apabila ingin belajar memasak dengan tujuan supaya mereka sudah terbiasa dan menjadi anak yang mandiri.

Melihat dari latar belakang tersebut, maka peneliti menganalisa serta mengkaji mengenai pola komunikasi pengasuh terhadap Anak Berkebutuhan Khusus (ABK) di Lembaga Kesejahteraan Sosial Anak (LKSA) Villa Do'a Yatim Sejahtera dalam membimbing serta mendidik Anak Berkebutuhan Khusus (ABK) supaya menjadi anak yang mandiri.

\section{METODE PENELITIAN}

Penelitian ini menggunakan jenis penelitian kualitatif yang bersifat deskrif dan menggunakan pendekatan komunikasi interpersonal. Peneliti memilih menggunakan jenis penelitian diatas dengan tujuan untuk mencari dan menemukan pengertian secara langsung dengan terjun kelapangan untuk mendapatkan pemahaman mengenai masalah yang diangkat dalam judul. Dengan begitu peneliti bisa mengetahui bagaimana pola komunikasi anak berkebutuhan khusus di vila do'a yatim sejahtera lembaga kesejahteraan anak (lksa) dalam membentuk kemandirian.

Dalam penelitian ini yang menjadi subjek penelitian adalah pengasuh aktif di Lembaga Kesejahteraan Sosial Anak (LKSA) Villa Do'a Yatim Sejahtera. Data premier penelitian ini yakni dengan observasi sebagai teknik yang utama disamping melakukan wawancara dan dokumentosi, untuk mengkonfirmasi kebenaran observasi butuh ditegaskan dengan gabungan wawancara serta dokumentasi. Menurut Miles dan Huberman (1994) kegiatan analisis ini terdiri dengan tiga 
tahapan yakni reduksi data (data Reduction), paparan data (data display), serta penarikan kesimpulan (conclusion drawing/verificatio). ${ }^{6}$

\section{HASIL DAN PEMBAHASAN}

Villa Do'a Yatim Sejahtera merupakan salah satu lembaga sosial yang berdiri sejak tahun 2009 artinya kurang lebih sudah berjalan selama 12 tahun dan awalnya kegiatan sosial tersebut hanya merawat anak yatim dhuafa, setelah berjalan beberapa waktu villa tersebut mendapatkan kepercayaan untuk bisa mendampingi anak-anak dan semua yang terkait permasalahan sosial, seperti anak berkebutuhan khusus (ABK), anak jalanan, anak berhadapan hukum (ABH), anak korban KDRT, pelecehan dan juga lansia. Awal berdiri Villa Do'a Yatim Sejahatera ini hanya ada 7 anak, dengan berjalannya waktu hingga saat ini sudah terhitung sebanyak 380 lebih anak yang sudah keluar dan juga masuk.

Jumlah keseluruhan yang tinggal di LKSA Villa Do'a Yatim Sejahtera saat ini, terdiri dari 33 laki-laki dan 20 perempuan, sudah termasuk 4 pengasuh aktif. yaitu 12 anak yati, 14 Dhuafa, 16 anak faktor keluarga, 4 Anak Berurusan Hukum $(\mathrm{ABH}), 3$ anak tanpa identitas, diantara 47 penduduk terdapat 5 anak yang menyandang disabilitas atau anak berkebutuhan khussu (ABK). Fokus penelitian ini adalah membahas mengenai tahapan dari komunikasi interpersonal serta pola komunikasi interpersonal pengasuh lemabag kesejahteraan sosial anak kepada anak berkebutuhan khussu (ABK) dalam membentuk kemandirian.

LKSA Villa Do'a Yatim Sejahtera memiliki dua lokasi yang berbeda yaitu lokasi yang pertama bertempatan di Bukit Djubel, desa Kembangbelor, Kec. Pacet. Kab. Mojokerto yang di peruntukan anak asuh perempuan, anak berkebutuhan khusus, lansia, dan anak laki-laki yang masih di bawah umur sedangkan lokasi yang kedua bertempatan di Dusun Mungkut, Desa Bendunganjati, Kabupaten Mojokerto yang di peruntukan anak laki-laki yang sudah dikategorikan remaja. ${ }^{7}$

\section{Tahapan Komunikasi Interpersonal Dalam Membentuk Kemandirian}

Komunikasi interpersonal merupaka salah satu jenis komunikasi yang dianggap sangat efektif dalam beberapa hal seperti mengubah perilaku, pendapat dan juga sikap seseorang, dikarenakan komunikasi interpersonal bersifat dialogis yakni percakapan. Dalam komunikasi interpersonal pengirim maupun penerima pesaan dapat berperan ganda, dalam artian keduanya bisa menjadi pendengar dan pembicara. Oleh sebab itu peneliti melakukan pengamatan yang lebih dalam untuk mengetahui proses interaksi yang berlangsung dari pengasuh terhadap anak

\footnotetext{
${ }^{6}$ Sugiyono, Metode Penelitian Kuantitatif, Kualitatif dan R\&D, (Bandung: Alfabeta, 2011),h. 244

${ }^{7}$ Wawancara dengan Ketua LKSA Villa Do'a Yatim Sejahtera bapak Mukhidin, pada tanggal 23 Juni 2021
} 
berkebutuhan khusus (ABK) untuk mengtahui umpan balik atau feedback yang sudah dilakukan pada proses komunikasinya.

Dalam hal ini komunikasi interpersonal yang dilakuakn pengasuh sangatlah berperan penting terkait pembinaan untuk memberikan sebuah bantuan dan juga arahan serta memberikan peringatan dan juga nasehat kepada seluruh anak asuhnya terlebih kepada anak berkebutuhan khusus (ABK). Untuk itu peneliti menggunakan teori penetrasi sosial guna menjelaskan hubungan dalam konteks komunikasi interpersonal yang berlangsung anatara pengasuh kepada anak berkebutuhan khusus di LKSA Villa Do'a Yatim Sejahtera.

Teori penetrasi sosial adalah teori yang membahas bagaimana proses peningkatan kedekatan secara terperinci dimulai dari pengungkapan diri, meningkatnya keakraban serta komunikasi, dan teori penetrasi sosial disini digunakan untuk mengetahui bagaimana proses pendekatan dari pengasuh kepada anak berkebutuhna khusus untuk bisa mencapai hubungan yang intim sehingga komunikasi interpersonal bisa berjalan dengan baik.

Dalam perkembangan hubungan pengasuh kepada anak berkebutuhan khusus ini peneliti menggunakan tahapan yang terdapat di teori penetrasi sosial. Tahap yang pertama pada teori penetrasi sosial ini adalah tahap orientasi yakni tahap mulainya perkenalan, dimana anak berkebutuhan khsus baru memulai untuk beradaptasi kepada pengasuh di LKSA Villa Do'a Yatim Sejahtera. Dalam tahap ini pengasuh tidak membutuhkan waktu yang begitu lama, karena di LKSA Villa Do'a Yatim Sejahtera ini menerapkan sistem kekeluargaan. Meskipun begitu tetap saja pengasuh mempunyai cara tersendiri untuk dekat kepada anak berkebutuhan khusus yang tentunya memiliki sifat serta karakter yang berbeda-beda.

Pada tahap orientasi, memahami sifat maupun karakter setiap anak berkebutuhan khussu juga termasuk bagian dari proses tahapan tersebut, yakni perkenalan dan juga pendekatan. Perkenalan ini meliputi nama, umur dan lain sebagainya. Sedangkan pendekatannya yakni seperti mengetahui seperti apa sifat, karakter dan seperti apa berkomunikasi kepad anak asuh lainnya kepada orang yang lebih dewasa, seusianya ataupun lebih muda tetap dibutuhkan pengasuh supaya hubungan antara pengasuh kepada anak berkebutuhan khusus dapat meningkat. Dalam hal ini terlihat dari pertama kali anak berkebutuhan khusus tiba di LKSA Villa Do'a Yatim Sejahtera dengan malu-malu.

Dari hasil observasi dan juga wawancara yang sudah dilakukan oleh peneliti selama terjun kelapangan yakni informan yang sudah melakukan tahapan ini adalah Mukhidin, Sutik dan juga Sopiyah. Dari hasil wwancara yang sudah dilakukan oleh peneliti kepada Mukhidin di tahap orientasi, yakni Mukhidin membutuhkan waktu kurang lebih 1 minggu untuk dapat melakukan interaksi kepada anak berkebutuhan khusus dari awal anak masuk ke LKSA Villa Do'a Yatim Sejahtera. Mukhidin mengataan bahwasannya di LKSA Villa Do'a Yatim 
Sejahtera ini menerapkan sistem kekeluargaan untuk membuat tahap perkenalan menjadi lebih mudah.

Dalam tahap orientasi ini Mukhidin sangat memahami bahwasannya setiap anak tentunya memiliki kasifat serta karakter yang berbeda-beda. Pada tahap ini Mukhidin memulai dengan mendekati anak berkebutuhan khusus untuk menanyakan hal-hal yang bersifat ringan. Anak berkebutuhan khusus dibiasakan memanggil dengan sebutan "mbak" kepada anak asuh yang usianya lebih tua diatasnya dan sebutan "mas" untuk laki laki yang usia di atasnya. Seperti yang di ungkapkan oleh Mukhidin yang merupakan pengasuh laki-laki di LKSA Villa Do’a Yatim Sejahtera. Sama halnya dengan yang dilakukan oleh Sutik pada tahap orientasi. Dari hasil wawancara yang sudah dilakukan peneliti kepada Sutik yaitu, tahap orientasi ini Sutik tidak membutuhkan waktu yang begitu lama untuk mulai berinteraksi kepada anak berkebutuhan khusus.

Selanjutnya Sopiyah yang juga pengasuh perempuan di LKSA Villa Do'a Yatim Sejahtera. Dari wawancara yang sudah dilakukan oleh peneliti kepada Sopiyah, yakni Sopiyah mumulai tahapan inii dengan melakukan pendekatan kepada anak berkebututuhan khusus terlebih dahulu yakni dengan selalu menyapa dan berusaha mengajak berkomunikasi, meskipun terkadang tidak mendapatkan respon, akan tetapi Sopiyah selalu mempunyai cara untuk menarik perhatian anak berkebutuhan khusus tersebut. Menurut Sopiyah meskipun anak berkebutuhan khusus tersebut usianya sudah belasan tahun akan tetapi mereka memiliki keterbatasan untuk melakukan hal-hal yang dilakukan anak-anak pada umumnya, mereka cenderung memiliki dunia sendiri dan suka bermain, baik yang laki-laki maupun yang perempuan. Dari situlah Sopiyah memulai interaksi kepada anak berkebutuhan khusus. ${ }^{8}$

Tahapan pertukaran eksplorasi merupakan tahapan dimana munculnya sebuah gerakan menuju ke arah keterbukaan yang lebih mendalam atau perluasan area publik yang terjadi pada individu. Dalam tahap pertukaran eksplorasi ini dapat dilihat adanya peningkatan yang lebih banyak lagi dari pada sebelumnya, dimana hal-hal yang awalnya pribadi menjadi terbuka seperti anak berkebutuhan khusus mulai menunujukan adanya keterbukaan kepada pengasuh. Semua yang diceritakan kepada pengasuh sesuai dengan apa yang tengah mereka rasakan saat itu. Dari hasil penelitian serta wawancara yang sudah dilakukan oleh peneliti yakni informan yang sudah melakukan tahapan ini adalah Mukhidin, Sutik, dan Sopiyah.

Berdasarkan hasil penelitian yang sudah dilakukan oleh peneliti kepada Mukhidin yang merupaka pengasuh ketua yayasan sekaligus pengasuh laki-laki, dimana tahap pertukaran eksploratif ini Mukhidin bercerita mengenai identitasnya yang berperan sebagai pengasuh sekaligus menggantikan peran orang tuanya di

\footnotetext{
${ }^{8}$ Wawancara bersama Ibu Shofia Pengasuh, tanggal 20Juni 2021 di LKSA Vilaa Do'a Yatim Sejahtera
} 
LKSA Villa Do'a Yatim Sejahtera dan anak berkebutuhan khususpun juga mulai terbuka kepada Mukhidin seperti bercerita tentang pengalaman pribadi ataupun menyampaikan apa yang mereka rasakan saat itu. Dalam tahap pertukaran eksploratif ini, komunikasi yang yang dilakukan oleh Mukhidin kepada anak berkebutuhan khusus berlangsung lebih santai dari sebelumnya. Komunikasi tersebut terkadang berlangsung dengan tatap muka dan juga berkelompok dengan anak asuh lainnya. hal tersebut dilakukan oleh Mukhidin supaya anak berkebutuhan khusus tidak merasa dibedakan dengan anak asuh lainnya.

Tahap pertukaran eksplorasi yang dilakukan oleh Sutik yakni dilakukan dengan cara berkelompok atau kumpul bersama, baik anak berkebutuhan khusus maupun anak asuh lainnya. Akan tetapi terkadang kita melakukannya secara face to face kepada anak berkebutuhan khusus yang perempuan, hal tersebut dikarenakan Sutik merupakan pengasuh perempuan. Dari hasil observasi yang dilakukan oleh peneliti, anak berkebutuhan khusus menceritakan seputar kegiatan nya sehari-hari kepada Sutik. Terkadang mereka juga bercerita mengenai keluarganya. Seperti yang disampaikan oleh Sutik. ${ }^{9}$

Selanjutnya tahap pertukaran eksploratif yang dilakukan oleh Sopiyah lebih sering secara face to face kepada anak berkebutuhan khusus. Informan C biasnya memanfaatkan waktu saat anak-anak asuh sedang beristirahat ataupun saat mengawasi anak asuhnlainnya sedang bermain maupun belajar. Sopiyah mendekati anak berkebutuhan khusus untuk menanyakan apa saja yang baru saja dia lakukan untuk memancingnya bercerita. Terkadang anak berkebutuhan khusus datang sendiri kepada Sopiyah untuk bercerita tanap ditanya sebelumnya. ${ }^{10}$

Tahap pertukaran afektif merupakan tahap dimana munculnya sebuah perasaan yang kritis serta evaluatif di level yang lebih dalam. Pada tahap ini interaksi yang terjadi juga lebih santai dan juga tanpa beban, serta seseorang yang menjadi lawan bicaranya mendapatkan timbal balik yang baik. Dalam tahap pertukaran afektif yang berlangsung antara pengasuh terhadap anak berkebutuhan khusus ini dapat dilihat ketika pengasuh sudah mulai memahami apa yang tengah dialami oleh anak berkebutuhan khusus tersebut seperti saat ada masalah dan pengasuh juga berusaha memahami yakni dengan mempelajari seperti apa sikap serta tingkah laku anak berkebutuhan khusus tersebut. Biasanya tingkah laku anak berkebutuhan khusus akan terlihat berbeda saat mereka sedang ada masalah. pengasuh akan menanyakan kepada anak berkebutuhan khsusu saat mengetahui jika anak berkebutuhan khusus tersebut sedang mempunyai masalah. Dari hasil

\footnotetext{
${ }^{9}$ Wawancara bersama Sekretaris LKSA Vilaa Do'a Yatim Sejahtera LKSA Villa Do'a Yatim Ibu Sutik, pada tanggal 21 Juni 2021

${ }^{10}$ Wawancara bersama Shofia, Pengasuh, tanggal 21Juni 2021 di LKSA Vilaa Do'a Yatim Sejahtera
} 
penelitian yang sudah dilakukan, maka peneliti mengamati bahwa yang melakukan tahap pertukaran afektif ini adalah Mukhidin, Sutik, dan Sopiyah.

Berdasarkan hasil observasi dan juga wawancara yang sudah dilakukan oleh peneliti kepada Mukhidin yaitu, pada tahap pertukaran afektif ini Mukhidin memahami jika anak berkebutuhan khusus tersebut memiliki masalah, untuk itu Mukhidin tindakan yang dilakukan oleh Mukhidin yaitu menghanpiri anak berkebutuhan khusus tersebut dan menanyakannya secara langsung. ${ }^{11}$

Sutik yakni pengasuh perempuan di LKSA Villa Do'a Yatim Sejahtera. Dari hasil observasi serta wawancara yang sudah dilakukan oleh peneliti kepada Sutik, dalam tahap ini Sutik yang mengawali komunikasi kepada anak berkebutuhan khusus dengan bertanya kepada setiap anak berkebutuhan khsuus terkait apa yang sedang mereka rasakan saat ini. ${ }^{12}$

Dalam tahap pertukaran afektif yang terjadi yaitu hal yang biasa diceritakan anak berkebutuhan khsusu kepada Sopiyah mengenai permasalahan dengan temanteman sekamar. seperti yang diungkapkan oleh Sopiyah. "Biasanya mereka sering cerita mengenai permasalahan dikamar, karena kamar anak berkebutuhan khsusu dan anak asuh lainnya kita sama kan. Jadi sering berdebat masalh piket, kegiatan dan lain sebagainya". 13

Pertukaran stabil ini dapat dilihat dari hubungan keduanya yakni anak pengasuh dan anak berkebutuhan khusus sudah mencapai tingkat dimana hal-hal yang bersifat priabadi menjabisa diketahui secara bersama, dimana seseorang bisa memprediksi reaksi emosional anrata satu sama lain. Hal ini bisa dilihat dari seperti apa pengasuh mengetahui apa yang tengah dirasakan oleh anak berkebutuhan khusus tersebut tanpa merka memulai bercerita.

Pengasuh bisa melihat hal tersebut melalui ekspresi wajahnya. Hal yang dilakukan pengasuh tentunya langsung mendekati anak tersebut untuk menanyakan apa yang sedang terjadi dan memberikan nasihat serta solusi untuk masalah yang tengah dialaminya. tahap ini disebut sebagai tahap pertukaran stabil karena pada tahap ini pengasuh sduah bisa menduga serta menilai dari setiap perilakuk anak asuhnya Dari hasil penelitian yang sudah dilakukan oleh peneliti selama observasi dan juga wawancara maka yang melakukan tahap pertukaran stabil ini terdapat tiga informan yaitu Mukhidin, Sutik dan Sopiyah.

Mukhidin dapat menegtahui ketika anak berkebutuhan khsuus tersebut sedang memiliki masalah dengan melihat ekspresi atau raut wajah anak berkebutuhan khsuus tersebut. Pada tahap ini Mukhidin memposisikan dirinya

${ }^{11}$ Wawancara bersama Ketua LKSA Vilaa Do'a Yatim Sejahtera LKSA Villa Do'a Yatim Bapak Mukhidin, pada tanggal 23 Juni 2021

${ }^{12}$ Wawancara bersama Sekretaris LKSA Vilaa Do'a Yatim Sejahtera LKSA Villa Do'a Yatim Ibu Sutik, pada tanggal 21 Juni 2021

${ }^{13}$ Wawancara bersama dengan Shofia, Pengasuh, tanggal 21Juni 2021 di LKSA Vilaa Do'a Yatim Sejahtera 
menjadi pengganti orang tua yakni berperan sebagai ayah untuk anak asuhnya. Mukhidin juga mempunyai cara sendiri dengan melakukan beberapa kegiatan yang tentunya melibatkan mereka terkhusus anak asuh laki-laki.

Sama halnya yang dilakukan oleh Sutik kepada anak berkebutuhan khusus. Dari observasi dan juga wawancara yang siudah dilakukan oleh peneliti kepada Sutik, dalam tahap pertukaran stabil ini dapat dilihat dari segi seperti apa pengasuh mengetahui serta memahami apa yang sedang dialami oleh anak berkebtuhan khsusu tersebut sebelum bercerita kepada nya. Seperti yang sudah di ungkapkan oleh Sutik: "liat dari ekspresi wajahya biasanya sudah bisa ditebak, misalnya ketika ada kegiatan, bisanya lebih sering sendiri dan gaada senyum-senyumnya, terkadang ditanya diam aja pas ditanya, biasanya juga kan ribut, terus kadang jahilin temannya lah ini kok diam aja terus menyendiri". ${ }^{14}$ Selanjutnya yakni Sopiyah yang tentunya juga memiliki cara atau upaya tersendiri untuk membuat anak berkebutuhan khusus merasa santai dan dekat dengannya seperti dekat kepada orang tua atau keluarganya sendiri.

Dalam tahap yang terakhitr yakni tahap pertukaran stabil ini pengasuh dapat menilai apa yang sedang dialami oleh anak asuhnya, dan tentunya pengasuh juga bisa memposisikan diri mreka sebagai apa saja sesuai dengan apa yang sedang terjadi.pada tahap in juga pengasuh berusaha supaya anak asuhnya bisa menghindari hal-hal yang berbau negatif, dengan cara selalu melakukan pembinaan seperti memberi nasihat, memberi motivasi, mengajari, dan bahkan ikut berperan melakukan hal yang mereka ajarkan.

\section{Komunikasi Interpersonal Pola Roda dan Pola Bintang}

Pola komunikasi yang dilakukan oleh pengasuh terhadap anak asuhnya $(\mathrm{ABK})$ dalam membentuk kemandirian yang tentunya hal tersebut sangatlah penting bagi anak berkebutuhan khusus (ABK) baik untuk dirinya sendiri saat ini maupun yang akan mendatang. Berdasarkan dari hasil penelitian yang sudah dilakukan oleh peneliti selama observasi dan juga wawancara, maka pengasuh menggunakan komunikasi interpersonal dengan pola roda dan pola bintang terhadap anak berkebutuhan khusus (ABK) dalam membentuk kemandirian.

Pola roda disini yaitu semua informasi yang sudah diarahkan oleh seseorang yang sedang berada di posisi sentral ataupun tengah. Seseorang yang menduduki posisi sentral ini dalam pola komunikasi antara pengasuh dan juga anak asuh yang dilakukan unutk membentuk kemandirian. Pegasuh atau informan berperan sebagai komunikator sedangkan anak asuh berperan sebagai komunikan. Dalam pola roda ini pengasuh (komunikator) memberikan sebuah arahan serta stimulus terhadap anak asuh (komunikan) tanpa adanya respon timbal balik dari

${ }^{14}$ Wawancara bersama Sekretaris LKSA Vilaa Do'a Yatim Sejahtera LKSA Villa Do'a Yatim Ibu Sutik, pada tanggal 21 Juni 2021 
anak-anak asuh (komunikan). Dalam pola roda ini komunikasi yang dilakukan di dominasikan oleh pengasuh yang berperan sebagai komunikator. Dalam hasil penelitian yang dilakukan oleh peneliti seperti observasi dan juga wawancara selama terjun ke lapangan yakni para informan yang melakukan pola roda ini adalah Mukhidin dan Sutik.

Pola komunikasi roda yang dilakukan oleh mukhidin yaitu setiap hari selasa dan jum'at setelah sholat ashar berjamaah dan mengaji, anak-anak tetap berada di masjid untuk mendengarkan mauidzah hasanah dari Mukhidin, saat itulah Mukhidin memberikan semacam mauidzah atau ceramah. Dalam pola komunikasi ini pengasuh yang menduduki posisi sentral memberikan nasihat, semangat dan juga motivasi untuk anak- anak asuhnya. Seperti yang diungkapkan oleh Mukhidin yang merupakan pengasuh laki-laki di LKSA Villa Do'a Yatim Sejahtera. ${ }^{15}$

Pola komunikasi roda yang dilakukan oleh Sutik untuk membentuk kemandirian anak berkebutuhan khusus yakni Sutik memberikan nasihat-nasihat dan juga motivasi terhadap anak berkebutuhan khusus supaya mau belajar serta berjuang sama seperti anak-anak seusianya. Selain itu pola komunikasi roda juga berlangsung saat adanya kegiatan training toilet untuk anak berkebutuhan khusus. Dimana kegiatan training toilet juga merupakan salah satu upaya pengasuh untuk membentuk kemandirian anak berkebutuhan khusus.

Pola komunikasi bintang yang berlangsung di LKSA Villa Do'a Yatim Sejahtera antara pengasuh dan juga anak berkebutuhan khusus menunujukan bahwasannya antara pengasuh dan juga anak berkebutuhan khusus bisa saling berinteraksi. Pada interaksi ini pengasuh tentunya memberikan kebebasan kepada anak berkebutuhan khusus untuk berbicara serta mengeluarkan pendapatnya. Dalam pola komunikasi bintang ini anggota-anggota memilki kekuatan yang sama dalam hal saling mempengaruhi. Pola komunikasi bintang di LKSA Villa Do'a Yatim Sejahtera dilihat dari bagaimana cara komunikasi yang sudah dilakukan oleh para pengasuh kepda anak berkebutuhan khusus dan juga antara anak berkebutuhan khusus kepada anak asuh lainnya. artinya pola komunikasi bintang berlangsung dengan dua arah dalam artian semua pihak terlibat. Berdasarkan hasil observasi dan juga wawancara yang sudah dilakukan peneliti dilapangan, informan yang melakukan pola komunikasi bintang adalah pengasuh Mukhidin, Sutik dan Sopiyah.

Pola komunikasi bintang yang berlangsung antara Mukhidin terhadap anak berkebutuhan khusus pada saat kegiatan santai seperti melakukan kegiatan otomotif mobil. Semua anak asuh laki-laki diajarkan mengenai ilmu otomotif mobil tak terkecuali anak berkebutuhan khusus. Hal tersebut dilakukan dengan tujuan supaya kelak anak-anak asuh bisa menjadi anak yang mandiri dan menjadi salah satu bekal mereka di dunia kerja kelak. Dari kegiatan tersebut terlihat bahwasannya aanak

${ }^{15}$ Wawancara bersama ketua LKSA Vilaa Do'a Yatim Sejahtera LKSA Villa Do'a Yatim bapak Mukhidin, pada tanggal 23 Juni 2021 
berkebutuhan khusus memberikan feedback atau respon yang baik terhadap Mukhidin, yakni dengan aktif bertanya serta banyak ikut membantu walaupun tidak terlalu memahami apa yang sudah diajarkan dan apa yang akan dikerjakan. ${ }^{16}$

Sama halnya dengan Sutik yang merupakan salah satu pengasuh perempuan di LKSA Villa Do'a Yatim Sejahtera. Dimana, hasil dari observasi yang sudah dilakukan oleh peneliti terhadap Sutik ketika peneliti berkunjung ke Villa Do'a Yatim Sejahtera, Sutik sedang berkumpul melakukan diskusi dengan anak berkebutuhan khusus di teras belakang. Dari diskusi tersebut Sutik memberikan motivasi kepada anak berkebutuhan khusus, mendengarkan cerita dari setiap anak berkebutuhan khusus. Kemudian merespon sesuai dari apa yang sudah diceritakan oleh anak berkebutuhan khusus. Dilihat dari hasil wawancara yang sudah peneliti lakukan dengan Sutik, maka pola komunikasi bintang yang sudah di terapkan oleh Sutik untuk membentuk kemandirian anak yaitu dengan melakukan sharing-sharing seperti adanya forum khusus untuk anak berkebutuhan khusus. Dimana komunikasi akan berlangsung secara efektif dan anak berkebutuhan khusus juga bisa dengan leluasa menyampaikan apa saja yang ada dalam fikiran mereka. ${ }^{17}$

Selanjutnya Sopiyah yang juga merupakan salah satu pengasuh perempuan di LKSA Villa Do'a Yatim Sejahtera. Dari hasil observasi dan juga wawancara yang dilakukan oleh peneliti, pola komunikasi bintang yang dilakukan oleh Sopiyah terhadap anak berkebutuhan khusus sama halnya dengan yang dilakukan oleh Sopiyah yakni dengan melakukan sharing kepada anak berkebutuhan khusus dan juga dengan anak asuh lainnya. Dalam pola komunikasi bintang ini komunikasi bintang ini berlangsung dengan dua arah.

Dari yang sudah dijelaskan di atas, maka peneliti memaknai bahwasannya pola komunikasi bintang yang sudah dilakukan tiga (3) informan yaitu Mukhidin, Sutik dan Sopiyah dengan beberapa cara di atas seperti melakukan sharing dan beberapa kegiatan lainnya untuk melatih serta memotivasi anak berkebutuhan khusus menjadi anak yang mandiri. Pola komunikasi yang berlangsung dua arah ini menghasilkan feedback yang baik untuk terhadap pengasuh, dimana anak berkebutuhan khusus dapat merespon apa yang sudah disampaikan oleh pengasuh yakni mengikuti arahan dari pengasuh, motivasi serta nasihat yang sudah di berikan.

Dari empat tahapan teori penetrasi sosial yaitu tahap orientasi, tahap pertukaran eksplorasi, tahap pertukaran afektif, dan juga tahap pertukaran stabil serta bentuk pola roda dan juga pola bintang yang dilakukan oleh pengasuh Lembaga Kesejahteraan Sosial Anak (LKSA) Villa Do'a Yatim Sejahtera terhadap anak berkebutuhan khusus benar-benar dapat dikatakan berhasil dalam membentuk kemandirian. Hal tersebut terbukti dari adanya perubahan anak berkebutuhan

${ }^{16}$ Wawancara bersama ketua LKSA Vilaa Do'a Yatim Sejahtera LKSA Villa Do'a Yatim bapak Mukhidin, pada tanggal 23 Juni 2021

${ }^{17}$ Wawancara B Sutik, tanggal 20 Juni 2021 di LKSA Vilaa Do'a Yatim Sejahtera 
khusus saat awal masuk ke Lembaga Kesejahteraan Sosial Anak (LKSA) Villa Do'a Yatim Sejahtera hingga anak berkebutuhan khusus tersebut sudah bisa melakukan kegiatan sehari-hari dengan mandiri. Seperti makan sendiri, mencuci baju, merapikan tempat tidur dan beberapa kegiatan lainnya. seperti yang di ungkapkan oleh ibu Sutik sebagai sekretaris sekailgus pengasuh di Lembaga Kesejahteraan Sosial Anak (LKSA) Villa Do’a Yatim Sejahtera.

\section{SIMPULAN DAN SARAN}

Berdasarkan dari hasil penelitian serta pembahasan yang sudah dilakukan oleh peneliti terkait tahapan komunikasi interpersonal dan pola komunikasi interpersonal yang dilakukan pengasuh terhadap anak berkebutuhan khusus dalam membentuk kemandirian dengan melalui empat tahapan yaitu Tahap Orientasi dimana tahap ini merupakan tahap paling utama atau tahap perkenalan. Seperti anak berkebtuhan khusus yang baru saja tiba dan mulai beradaptasi di LKSA Villa Do'a Yatim Sejahtera. Dalam tahap orientasi ini pengasuh tidak terlalu membutuhkan waktu yang lama untuk mendekati anak berkebutuhan khsuus. Pada tahap ini dilakukan oleh seluruh informan yakni Mukhidin, Sutik, dan Sopiyah.

Tahap pertukaran eksploratif yaitu tahap dimana hubungan pengasuh kepada anak berkebutuhan khsusu terjadi lebih santai dan menuju ke arah yang lebih akrab. Pada tahap ini, dimaana yang awalnya merupakan hal yang privasi beralih menjadi publik. Pada tahap ini juga dilakukan oleh semua informan yaitu Mukhidin, Sutik, dan Sopiyah. Tahap pertukaran afektif yang terjadi antara pengasuh kepada anak berkebutuhan khusus di LKSA Villa Do'a Yatim Sejahtera ini berawal dari pengasuh yang sudah mulai memahami apabila anak asuhnya atau anak berkebutuhan khsusu tersebut sedang memiliki masalah. pada tahap ini dilakukan oleh semua informan yakni Mukhidin, Sutik, dan Sopiyah. Tahap Pertukaran Stabil yang terjadi antara pengasuh kepada anak berkebutuhan khussus di LKSA Villa Do'a Yatim Sejahtera ini dapat dilihat dari seperti apa pengasuh mengetahui apa yang tengah dirasakan oleh anak berkebutuhan khsus tanpa adanya cerita terlebih dahulu. Dalam tahap pertukaran stabil ini dilakukan oleh seluruh informan yakni Mukhidin, Sutik, dan Sopiyah.

Pola komunikasi yang digunakan pengasuh kepada anak berkebutuhan khusus dalam membentuk kemandirian di LKSA Villa Do'a Yatim Sejahtera yaitu Pola roda dimana pola yang dilakukan oleh pengasuh kepada anak berkebutuhan khusus yakni dengan memberikan arahan melalui kegiatan an rutin di LKSA Villa Do'a Yatim Sejahtera yakni biasa disebut dengan mauidzah. Kegiatan ini bersifat satu arah yakni komunikasi yang berlangsung lebih dominan kepada pengasuh yang berperan sebagai komunikator, dan yang melakukan pola roda ini yakni Mukhidin dan Sutik.

Pola bintang yang dilakukan oleh pengasuh kepada anak berkebutuhan khusus ini mempunyai kekuatan yang sama dalam hal saling mempengaruhi, artinya 
antara pengasuh dan juga anak berkebutuhan khusus dapat berinteraksi dan memberikan timbal balik yang baik dari apa yang sudah disampaikan oleh pengasuh kepada anak berkebutuhan khusus. Dalam hal ini pola bintang dilakukan oleh Mukhidin, Sutik, dan Sopiyah.

\section{Saran}

Dari penelitian ini diharapkan bisa memberikan masukan terkait perkembangan ilmu komnikasi terkhusus mengenai pola komunikasi yang dilakukan oleh pengasuh kepada anak berkebutuhan khusus anatau anak asuh lainnya di panti. Harapan dari peneliti sendiri yakni dengan di ketahui mengenai pola komunikasi yang seperti apa dilakukan oleh pengasuh kepada anak berkebutuhan khusus untuk membentuk kemandirian, bisa membantu anak berkebutuhan khusus yang sama-sama berada dalam lingkungan panti asuhan bisa bersaing dengan anak pada umumnya yang berada di lingkungan keluarga.

\section{DAFTAR PUSTAKA}

Depdiknas.2004, "Pedoman Peneyelenggaraan Pendidikan Terpadu/Inklusi Jakarta: DitPLB. h. 2

Djmarah, S. B. (2017). Pola Asuh Orang Tua dan Komunikasi Dalam Keluarga. Jakarta: PT Rineka .

Effendy, O. U. (2018). Dinamika Komuniikasi. Bandung: PT Remaja Rosdakarya.

Hasan. (1996). Remaja Berkualitas Problematika Remaja dan Solusinya. Yogyakarta: Pustaka Pelajar.

Inah, E. N. (2013). Peranan Komunikasi Dalam Pendidikan. Al-Ta'dib.

Morissan. (2013). Teori Komunikasi Individu Hingga Massa. Jakarta: Prenadamedia Group.

Mulyana, D. (2016). Ilmu Komunikasi Suatu Pengantar. Bandung: PT Remaja Rosdakarya.

Pioh, E. Y. (2017). Peran Pengasuh Dalam Meningkatkan Kemandirian Anak Disabilitas Netra di Panti Sosial Bartemeus Manado. E-Jurnal Acta Diurna.

Ptriana, E. (2014). Komunikasi Interpersonal Yang Berlangsung ANtara Pembimbing Kemasyarakatan dan Keluarga Anak Pelaku Pidana di Bapas Surakarta. Journal Of Rural and Develepment.

Rundengan, N. (2013). Pola Komunikasi Antarpribadi Mahasiswa papua di Lingkungan Fakultas Ilmu Sosial Dalam Politi Universitas Sam Ratulangi. Journal Acta Diurna.

Sentosa, A. T. (2015). Pola Komunikasi Dalam Proses Interaksi Sosial di Pondok Pesantren Nurul Islam Samarinda. e Jurnal Ilmu Komunikasi.

Sugiyono. (2011). Metode Penelitian Kuantitatif, Kualitatif dan R\&D. Bandung: Alfabeta. 
Pola Komunikasi Interpersonal dalam Membentuk Kemandirian Anak Berkebutuhan Khusus 